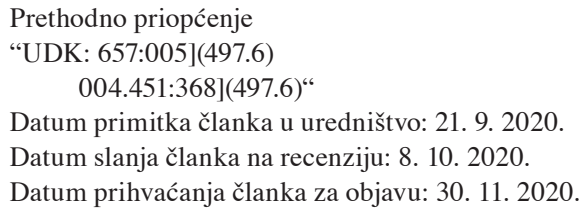

Doc. dr. sc. Jovana Zoroja

\title{
KORIŠTENJE POSLOVNIH SIMULACIJSKIH IGARA U OBRAZOVNOM PROCESU IZ PODRUČJA EKONOMIJE U REPUBLICI HRVATSKOJ (2009. vS. 2020.)
}

\section{USING SIMULATION GAMES IN THE EDUCATIONAL PROCESS IN THE FIELD OF ECONOMICS IN THE REPUBLIC OF CROATIA (2009 vs 2020)}

SAŽETAK: Intenzivan razvoj i korištenje informacijsko-komunikacijskih tehnologija pozitivno utječe na povećanu primjenu različitih programa i alata u obrazovnom procesu. Simulacijske igre predstavljaju inovativan i fleksibilan pristup učenju, jer kreiraju poslovno okruženje koje sudionicima omogućuje učenje kroz iskustvo. Aktivno sudjelovanje u simulacijskim igrama osigurava sudionicima bolje razumijevanje teorijskog znanja te njegovu primjenu u različitim poslovnim situacijama. Ciljevi rada su dvostruki. Prvi cilj rada je predstaviti dobivene rezultate o primjeni simulacijskih igara u nastavnom procesu na ekonomskim fakultetima u Republici Hrvatskoj u 2020. godini. Drugi cilj rada je usporediti dobivene rezultate o primjeni simulacijskih igara u 2020. godini s rezultatima iz 2009. godine. Namjera rada je utvrditi sličnosti i razlike stavova ispitanika o primjeni simulacijskih igara u nastavnom procesu u 2009. godini s rezultatima iz 2020. godine. Istraživanje je provedeno putem anketnog upitnika u kojem su sudjelovala 124 ispitanika koja su zaposlena na ekonomskim fakultetima u Republici Hrvatskoj. Dobiveni rezultati iz 2009. i 2020. godine uspoređeni su primjenom hi-kvadrat i t-testa. Ispitanici se slažu kako simulacijske igre doprinose zadovoljstvu studenata te kako pridonose kvaliteti obrazovnog procesa. Rezultati ponovljenog istraživanja u 2020. godini ne ukazuju na postojanje velikih razlika u primjeni simulacijskih igara u obrazovnom procesu. Nedovoljna primjena simulacijskih igara u nastavi je i dalje prisutna, unatoč prednostima primjene simulacijskih igara.

KLJUČNE RIJEČI: simulacijske igre, obrazovanje, Republika Hrvatska

ABSTRACT: Intensive development and usage of information and communication technologies has a positive effect on the increased application of various programs and tools

Doc. dr. sc. Jovana Zoroja, Ekonomski fakultet Zagreb, Katedra za informatiku, Trg J. F. Kennedyja 6, 10000 Zagreb, Hrvatska, email: jzoroja@efzg.hr 
in the educational process. Simulation games represent an innovative and flexible approach in learning, as they create a business environment that allows participants to learn through experience. Active participation in simulation games enable participants better understanding of the theoretical knowledge and its application in various business situations. Goals of the paper are twofold. The first goal of the paper is to present given results regarding usage of simulation games in education at the faculties of economics in Croatia in 2020. The second goal of the paper is to compare the results on the usage of simulation games from 2020 with the results of a survey conducted in 2009. The purpose of the research is to investigate the similarities and differences of respondents' attitudes about the usage of simulation games in the teaching process in the last eleven years. The research was conducted via questionnaire on a sample of 124 respondents employed at the faculties of economics in the Republic of Croatia. The obtained results from 2009 and 2020 were compared using chi-square and t-test. Respondents agree that simulation games contribute to students' satisfaction and increase the quality of the educational process. The results of the repeated research in 2020 do not indicate the existence of a large differences in the usage of simulation games in the educational process. Insufficient usage of simulation games in teaching is still present, despite the advantages of using simulation games.

KEY WORDS: simulation games, education, Croatia

\section{UVOD}

Simulacijske igre se dugo koriste kao jedan od vrijednih alata u nastavi te imaju snažan utjecaj na obrazovni proces. Prije svega zbog aktivnog uključivanja studenata u nastavu kao i radi poticanja studenata na primjenu teorijskog znanja u stvarnim situacijama. Sudionici su izrazito motivirani primjenom aktivnog pristupa obrazovanju kroz sudjelovanje u stvarnim poslovnim situacijama te povratnim informacijama o donesenim odlukama (Mohsen, et. al., 2019; Goi, 2019). Kroz simulacijske igre predstavljene su različite poslovne situacije u kojima sudionici preuzimaju pojedine uloge koje zahtijevaju i određenu razinu odgovornosti, kao i suočavanje s izazovima i problemima, što podrazumijeva donošenje odluka i snalaženje u rješavanju problema (Nkhoma et al., 2014; Hu, Min Wong, Adesope, Taylor, 2020). Natjecateljski odnos među sudionicima ih motivira i potiče da budu bolji od konkurencije. Primjena simulacijskih igara u obrazovanju se svake godine povećava, jer se intenzivno razvijaju i primjenjuju informacijsko-komunikacijske tehnologije, ali i inovativni načini obrazovanja (Vlachopoulos, Makri, 2017).

Namjera rada je utvrditi stav i percepciju ispitanika o primjeni simulacijskih igara na ekonomskim fakultetima u Republici Hrvatskoj u 2020. godini. Prvo empirijsk istraživanje je provedeno 2009. godine kako bi se istražilo sljedeće: (i) doprinos pojedinih nastavnih metoda zadovoljstvu studenata, (ii) razlike prilikom primjene različitih nastavnih metoda u obrazovanju, (iii) prednosti za studente prilikom primjene simulacijskih igara i (iv) utjecaj primjene simulacijskih igara na kvalitetu izvođenja nastave. Istraživanje je ponovljeno 2020. godine. Ciljevi rada su sljedeći: (i) predstaviti dobivene rezultate o primjeni simulacijskih igara u nastavnom procesu na ekonomskim fakultetima u Republici Hrvatskoj i (ii) usporediti dobivene rezultate s rezultatima iz 2009. godine kako bi se utvrdile sličnosti i 
razlike stavova ispitanika o primjeni simulacijskih igara u nastavnom procesu s obzirom da je prošlo 11 godina od provedbe prvog istraživanja.

Rad se sastoji od pet poglavlja. U uvodnom poglavlju definirane su simulacijske igre, predstavljen je cilj rada i navedena je struktura poglavlja. Opis i karakteristike simulacijskih igara, njihove prednosti i nedostaci kao i primjena u različitim područjima je opisana u drugom poglavlju. Metodologija istraživanja kao i prikupljeni podaci je prikazana u trećem poglavlju. U četvrtom poglavlju predstavljeni su rezultati iz 2009. i 2020. godine te njihova usporedba. Zaključna razmišljanja su navedena u petom poglavlju rada.

\section{POSLOVNE SIMULACIJSKE IGRE U OBRAZOVANJU}

Brzi napredak i primjena informacijsko-komunikacijske tehnologije, kao i promjena $\mathrm{s}$ tradicionalnog modela učenja prema edukaciji koja je orijentirana na sudionike nastavnog procesa, dodatno su potaknuli integraciju simulacijskih igara u obrazovanje (Vlachopoulos, Makri, 2017). Inovativne nastavne metode podrazumijevaju aktivno sudjelovanje studenata kao i promjenu modela obrazovanja koje potiče učenje kroz iskustvo umjesto dosadašnjeg modela učenja slušajući. Upravo primjena simulacijskih igara predstavlja ključnu ulogu u obrazovanju studenata, jer kroz kombinaciju iskustva, spoznaje i percepcije potiču studente na aktivan rad i bolje razumijevanje nastavnih materijala (Zulfiqar et. al., 2018). Osim u obrazovanju, primjena simulacijskih igara je raširena i na ostala područja, kao što su: znanost, menadžment, zrakoplovstvo, vojska, medicina, inženjerstvo (Mawhirter, Garofalo, 2016; Dankbaar et. al., 2016; Strahilov, Damrath, 2015).

Simulacijski sustav prikazuje virtualno okruženje koje predstavlja stvarne poslovne situacije u kojima sudionici trebaju izvršiti određene zadatke i donositi poslovne odluke (Gredler, 2004). Ovisno o području u kojem se primjenjuje, simulacijski sustav se temelji na teoriji i praktičnom radu koje sudionici trebaju usvojiti kako bi kroz snalaženje u stvarnoj situaciji stekli praktično znanje i potrebno iskustvo. Međusobna suradnja te komunikacija omogućava bolje razumijevanje i primjenu usvojenog znanja, ali i razvoj poslovnih i kognitivnih vještina (Siewiorek 2013; Ranchhod, 2014). Sudionici usvajaju znanje kroz iskustvo što ih motivira i dodatno potiče na rad i učenje (Fasli, Michalakopoulos, 2006). Sudjelovanjem u simulacijskoj igri, sudionici međusobno surađuju, razmjenjuju ideje, donose poslovne odluke, ali bez štetnih posljedica na poslovanje. Unatoč tome što nema rizika prilikom donošenja odluka važnih za poslovanje, sudionici dobiju povratnu informaciju te imaju priliku analizirati donesene odluke kako bi bolje razumjeli što su pogrešno odnosno dobro odradili kako bi kasnije u stvarnom poslu bili uspješniji. Upravo analiza koraka koje su sudionici napravili tijekom simulacijske igre i povratna informacija, najviše doprinose boljem razumijevanju zadataka i uspješnijem rezultatu (Nkhoma et. al., 2014).

Tradicionalne nastavne metode, kao što su predavanja, studije slučajeva i diskusije, omogućuju studentima bolje razumijevanje teorijskog dijela obrazovanja, ali bez praktične primjene naučenoga. Primjenom poslovnih simulacijskih igara koje potiču aktivno sudjelovanje dodatno se obogaćuje predavanje i ostale tradicionalne nastavne metode (Rutten et. 
al., 2012; Clark et. al., 2016). Upravo kroz primjenu simulacijskih igara, studenti razvijaju vještinu učenja i kritičkog razmišljanja, spremniji su na rad i učenje, surađuju i komuniciraju s drugim sudionicima, bolje upravljaju vremenom i konfliktima, razvijaju kognitivne sposobnosti te stječu iskustvo bez stvarnih posljedica (Bell and Loon, 2015; Lainemaa and Nurmib, 2006). Osim toga, korištenje simulacijskih igara nije ograničeno na vrijeme i mjesto, te potiče rad između studenata iz različitih kultura i područja (Zulfiqar et. al., 2018). Primjena simulacijskih igara ne utječe samo na poboljšanje vještina i sposobnosti studenata, već ima pozitivan utjecaj i na njihove ostvarene rezultate tijekom obrazovanja (De Smale et. al., 2015; Sanina, Kutergina, Balashov, 2020).

Unatoč mnogobrojnim prednostima, postoje i izazovi s kojima se susreću i nastavnici i studenti prilikom primjene simulacijskih igara. Najveća prepreka u primjeni predstavlja cijena odnosno troškovi korištenja simulacijskih igara (Bell, et. al., 2008). Potrebno je osigurati financijska sredstva za izvođenje simulacijske igre tijekom jednog semestra za svakog pojedinog studenta na određenom kolegiju. Osim toga, važno je da nastavnik ima kompetencije i vještine da odabere kvalitetnu simulacijsku igru koja će pratiti teorijski dio nastave i koja će uistinu doprinijeti edukaciji studenata. Također, nastavnici trebaju biti spremni koristiti novu tehnologiju, nove nastavne metode te imati potrebno znanje kako bi zainteresirali studente i potaknuli ih na sudjelovanje te omogućili im kvalitetnu povratnu informaciju o njihovu radu (Zulfiqar et. al., 2018).

Iz svega navedenog moguće je zaključiti kako simulacijske igre imaju značajan potencijal u obrazovanju studenata kao alat koji im omogućuje praktičnu primjenu stečenog teorijskog znanja te stjecanje neophodnih poslovnih vještina. Stoga je važno kroz znanstvena i stručna istraživanja potaknuti njihovu primjenu ne samo u obrazovanju, već i u ostalim područjima.

\section{METODOLOGIJA ISTRAŽIVANJA}

\section{Istraživanje provedeno 2009. godine}

Primarno empirijsko istraživanje provedeno je primjenom anketnog upitnika u rujnu 2009. godine među nastavnicima zaposlenima na ekonomskim fakultetima u Republici Hrvatskoj. U istraživanju je sudjelovalo 50 ispitanika kojima je anketni upitnik poslan elektroničkom poštom.

Cilj istraživanja je bio utvrditi stav i percepciju ispitanika o mogućnostima primjene simulacijskih igara u obrazovnom procesu, njihova usporedba s drugim nastavnim metodama, kao i doprinos zadovoljstvu studenata korištenjem simulacijskih igara u obrazovanju te njihov utjecaj na poboljšanje provođenja obrazovnog procesa.

U istraživanju iz 2009. godine je $54 \%$ ispitanika ženskog spola i $46 \%$ ispitanika muškog spola (Zoroja, 2009). Polovina ispitanika su asistenti, dok je najmanji udio (16\%) izvanrednih i redovitih profesora te docenata (18 \%). U istraživanju su sudjelovali nastavnici s ekonomskih fakulteta u Zagrebu, Osijeku, Rijeci, Splitu i Opatiji. Ispitanici su odgovarali na pitanja primjenom Likertove ljestvice stavova. Navedene tvrdnje su ocjenjivali ocjenama od jedan do pet. Prikupljeni odgovori analizirali su se korištenjem metoda i tehnika deskriptivne i inferencijalne statistike primjenom softverskog alata Statistica. 
Istraživanje provedeno 2020. godine

Primarno empirijsko istraživanje ponovljeno je u kolovozu 2020. godine također među nastavnicima koji predaju na ekonomskim fakultetima u Republici Hrvatskoj. U istraživanju provedenom 2020. godine sudjelovala su 124 ispitanika kojima je anketni upitnik također poslan elektroničkom poštom.

Cilj ponovljenog primarnog istraživanja iz 2020. godine je predstaviti dobivene rezultate o primjeni simulacijskih igara u obrazovnom procesu iz područja ekonomije te ih usporediti s rezultatima istraživanja iz 2009. godine. Namjera je usporediti stavove i percepciju nastavnika zaposlenih na ekonomskim fakultetima u Republici Hrvatskoj s obzirom na primjenu simulacijskih igara u nastavi i njihovom doprinosu i utjecaju na izvođenje obrazovnog procesa nakon proteka od 11 godina od početnog istraživanja.

U provedenom istraživanju iz 2020. godine sudjelovao je veći broj ispitanika s obzirom da je anketni upitnik poslan nastavnicima na više ekonomskih fakulteta u odnosu na istraživanje iz 2009. godine. Prema rezultatima istraživanja iz 2020. godine, 52 \% ispitanika su osobe ženskog spola i $48 \%$ ispitanika muškog spola. Otprilike je jednak udio asistenata (24\%) i redovitih profesora (25\%), odnosno četvrtina ispitanika. Trećina ispitanika su docenti, dok je u zvanju izvanrednog profesora $21 \%$ ispitanika. U istraživanju su sudjelovali nastavnici s ekonomskih fakulteta u Zagrebu, Osijeku, Rijeci, Splitu, Opatiji, Dubrovniku i Varaždinu. S obzirom da su pitanja ponovljena, ispitanici su pitanja ocjenjivali primjenom Likertove ljestvice stavova od jedan do pet. Analiza odgovora provedena je u softverskom programu Statistica primjenom metoda i tehnika deskriptivne i inferencijalne statistike kako bi se utvrdile razlike između stavova ispitanika o primjeni simulacijskih igara u obrazovnom procesu nakon 11 godina.

Rezultati istraživanja pokazali su kako je u 2009. godini približno jednak udio muških (28 \%) i ženskih (23\%) osoba zaposlenih na ekonomskim fakultetima koji koriste simulacijske igre, što čini otprilike četvrtinu ispitanika (Tablica 1). Ipak, veći je udio ispitanika koji ne koriste simulacijske igre. S obzirom na akademski stupanj ispitanika, otprilike je jednak udio asistenata $(22 \%)$ i docenata $(20 \%)$ koji koriste simulacijske igre u nastavi dok je udio izvanrednih i redovitih profesora nešto viši (31 \%). Rezultati istraživanja su pokazali kako je u 2020. godini znatno veći udio osoba muškog spola (22 \%) koji koriste simulacijske igre u nastavi u odnosu na osobe ženskog spola (8 \%). Ipak, veći je udio ispitanika koji uopće ne koriste simulacijske igre. S obzirom na akademski stupanj ispitanika, otprilike je jednak udio asistenata (17\%), docenata (14\%) te izvanrednih i redovitih profesora (13\%) koji koriste simulacijske igre u nastavi. Rezultati hi-kvadrat testa pokazali su statistički značajnu razliku uz $1 \%$ vjerojatnosti s obzirom na spol ispitanika u 2020. godini $\left(\chi^{2}=7,686 ; p\right.$-vrijednost $\left.=0,005\right)$, dok prema akademskom stupnju nema statistički značajne razlike $\left(\chi^{2}=0,692 ; p\right.$ - vrijednost $\left.=0,707\right)$. Može se zaključiti kako akademski stupanj nema značajniji utjecaj na donošenje odluke o korištenju simulacijskih igara, dok je uloga spola promijenjena. Udio žena koje koriste simulacijske igre se smanjio te bi tek trebalo istražiti zbog kojih razloga se ova promjena dogodila te je li takva promjena trajna, uzevši u obzir kros-sekcionalni karakter oba istraživanja.

Tablica 2 prikazuje korištenje simulacijskih igara u nastavi u 2009. te u 2020. godini. Podaci su približno jednaki za sljedeće dvije kategorije: (i) trenutno koriste simulacijske igre u nastavi (15\% ispitanika u 2020. godini i $16 \%$ ispitanika u 2009. godini); (ii) u jed- 
Tablica 1. Demografske karakteristike ispitanika iz uzorka s obzirom na korištenje simulacijskih igara

\begin{tabular}{|c|c|c|c|}
\hline Karakteristike ispitanika & $\begin{array}{c}\text { Korištenje } \\
\text { simulacijskih } \\
\text { igara }\end{array}$ & $\begin{array}{c}\text { Ne korištenje } \\
\text { simulacijskih } \\
\text { igara }\end{array}$ & Hi-kvadrat \\
\hline \multicolumn{4}{|l|}{ 2009. godina } \\
\hline \multicolumn{4}{|l|}{ Spol } \\
\hline Muškarci & $28 \%$ & $72 \%$ & \multirow{2}{*}{$\begin{array}{c}\chi^{2}=0,439 \\
\text { p- vrijednost }=0,507\end{array}$} \\
\hline Žene & $23 \%$ & $77 \%$ & \\
\hline \multicolumn{4}{|l|}{ Akademski stupanj } \\
\hline Asistent & $20 \%$ & $80 \%$ & \multirow{3}{*}{$\begin{array}{c}\chi^{2}=3,792 \\
\text { p- vrijednost }=0,155\end{array}$} \\
\hline Docent & $22 \%$ & $78 \%$ & \\
\hline Izvanredni i redoviti profesori & $31 \%$ & $69 \%$ & \\
\hline \multicolumn{4}{|l|}{ 2020. godina } \\
\hline \multicolumn{4}{|l|}{ Spol } \\
\hline Muškarci & $22 \%$ & $78 \%$ & \multirow{2}{*}{$\begin{array}{c}\chi^{2}=7,686 \\
\text { p- vrijednost } \\
=0,005^{* * *}\end{array}$} \\
\hline Žene & $8 \%$ & $92 \%$ & \\
\hline \multicolumn{4}{|l|}{ Akademski stupanj } \\
\hline Asistent & $17 \%$ & $83 \%$ & \multirow{3}{*}{$\begin{array}{c}\chi^{2}=0,692 \\
\text { p- vrijednost }=0,707\end{array}$} \\
\hline Docent & $14 \%$ & $86 \%$ & \\
\hline Izvanredni i redoviti profesori & $13 \%$ & $87 \%$ & \\
\hline
\end{tabular}

Izvor: istraživanje autorice (2020), Zoroja (2009.)

Bilješka: *** statistički značajno uz $1 \%$ vjerojatnosti

Tablica 2. Korištenje simulacijskih igara u nastavi ispitanika iz uzorka

\begin{tabular}{|c|c|c|c|}
\hline Simulacijske igre u nastavi & 2020. godina & 2009. godina & Hi-kvadrat \\
\hline Trenutno koriste & $15 \%$ & $16 \%$ & \multirow{4}{*}{$\begin{array}{c}\chi^{2}=12,580 \\
\text { p- vrijednos } \\
=0,006^{* * *}\end{array}$} \\
\hline U jednom trenu su koristili & $12 \%$ & $10 \%$ & \\
\hline Planiraju koristiti & $56 \%$ & $36 \%$ & \\
\hline Ne koriste niti planiraju koristiti & $17 \%$ & $38 \%$ & \\
\hline
\end{tabular}

Izvor: istraživanje autorice (2020), Zoroja (2009).

Bilješka: *** statistički značajno uz $1 \%$ vjerojatnosti

nom trenutku su koristili simulacijske igre u nastavi (12\% ispitanika u 2020. godini i $10 \%$ ispitanika u 2009. godini). Što se tiče namjere korištenja, može se uočiti razlika između rezultata iz 2009. godine i 2020. godine. U 2020. godini, udio ispitanika koji planiraju koristiti simulacijske igre u nastavi iznosi više od $50 \%$ (56 \%), dok je otprilike trećina ispitanika u 2009. godini navela kako planira koristiti simulacijske igre u nastavi (36 \%). Osim toga, u 2020. godini poprilično je nizak udio ispitanika koji ne koriste niti planiraju 
koristiti simulacijske igre u nastavi (17\%), dok je 2009. godine udio ispitanika koji ne koriste niti planiraju koristiti simulacijske igre iznosio $38 \%$.

Rezultati hi-kvadrat testa pokazali su kako statistički značajna razlika uz $1 \%$ vjerojatnosti postoji s obzirom na korištenje simulacijskih igara u 2020. i 2009. godini. Iako je gotovo jednak udio ispitanika koji trenutno koriste simulacijske igre u nastavi u obje promatrane godine (15\% u 2020. godini i $16 \%$ u 2009. godini), udio ispitanika koji planiraju koristiti simulacijske igre u obrazovanju znatno se povećao (56\% u 2020. godini i $35 \%$ u 2009. godini).

\section{REZULTATI I USPOREDBA ISTRAŽIVANJA (2009. VS. 2020.)}

U ovom dijelu rada prikazat će se rezultati istraživanja o primjeni simulacijskih igara u obrazovnim institucijama u Republici Hrvatskoj provedenog 2009. godine, kao i rezultati ponovljenog istraživanja u 2020. godini. Dobiveni rezultati o percepciji ispitanika vezano uz primjenu simulacijskih igara u radu sa studentima su se usporedili kako bi se utvrdilo postoje li razlike s obzirom da je istraživanje ponovljeno nakon 11 godina. Predstavljeni su rezultati iz sljedećih područja: pojedine nastavne metode i njihov doprinos zadovoljstvu studenata, razlika prilikom primjene simulacijskih igara i ex-chatedra nastave, doprinos zadovoljstvu studenata primjenom simulacijskih igara te utjecaj simulacijskih igara na poboljšanje izvođenja obrazovnog procesa.

\subsection{Nastavne metode i njihov doprinos zadovoljstvu studenata}

U Tablici 3 navedene su pojedine nastavne metode s obzirom na doprinos zadovoljstvu studenata. Ispitanici su na Likertovoj ljestvici od jedan do pet procijenili je li navedene nastavne metode pridonose zadovoljstvu studenata u nastavi. Otprilike dvostruko više ispitanika u 2009. godini je istaknulo kako studije slučajeva (40 \%) i simulacijske igre (40\%) dosta doprinose zadovoljstvu studenata u odnosu na ex-chatedra nastavu (22 \%). Također, više od polovine ispitanika smatra kako simulacijske igre znatno pridonose zadovoljstvu studenata (54\%).

Prema rezultatima iz 2020. godine, dvostruko više ispitanika smatra kako aktivno sudjelovanje studenata (41 \%) i studije slučajeva (48 \%) dosta doprinose zadovoljstvu studenata u odnosu na ex-chatedra nastavu ( $23 \%$ ) i primjenu simulacijskih igara (23\%). Razlika koja se također može uočiti je kako rezultati za 2009. i 2020. godinu pokazuju jednaki udio ispitanika koji smatraju kako ex-chatedra malo pridonosi zadovoljstvu studenata (2009.: $28 \%, 2020 .: 27 \%$ ). Međutim, rezultati se uvelike razlikuju s obzirom na primjenu simulacijskih igara i njihov doprinos zadovoljstvu studenata, jer niti jedan ispitanika iz 2009. godine ne smatra kako simulacijske igre malo doprinose zadovoljstvu studenata, dok 2020. godine gotovo trećina ispitanika (27 \%) smatra kako simulacijske igre malo doprinose zadovoljstvu studenata. Promatrajući dobivene rezultate za 2009. i 2020. godinu, moguće je zaključiti kako se najviše ispitanika slaže kako zadovoljstvu studenata najviše doprinosi aktivno sudjelovanje u nastavi i studije slučajeva. 
Tablica 3. Nastavne metode koje najviše pridonose zadovoljstvu studenata prema procjeni ispitanika iz uzorka

\begin{tabular}{|c|c|c|c|c|c|}
\hline \multirow[b]{2}{*}{ Nastavne metode } & \multicolumn{5}{|c|}{ Ispitanici u postocima } \\
\hline & $\begin{array}{c}\text { Ne } \\
\text { pridonose } \\
\text { zadovoljstvu } \\
\text { studenata }\end{array}$ & $\begin{array}{c}\text { Malo } \\
\text { pridonose } \\
\text { zadovoljstvu } \\
\text { studenata }\end{array}$ & $\begin{array}{c}\text { Srednje } \\
\text { pridonose } \\
\text { zadovoljstvu } \\
\text { studenata }\end{array}$ & $\begin{array}{c}\text { Dosta } \\
\text { pridonose } \\
\text { zadovoljst- } \\
\text { vu stude- } \\
\text { nata }\end{array}$ & $\begin{array}{c}\text { Znatno } \\
\text { pridonose } \\
\text { zadovoljst- } \\
\text { vu stude- } \\
\text { nata }\end{array}$ \\
\hline \multicolumn{6}{|l|}{ 2009. godina } \\
\hline Ex-chatedra & $20 \%$ & $28 \%$ & $30 \%$ & $22 \%$ & $0 \%$ \\
\hline $\begin{array}{l}\text { Aktivno sudjelo- } \\
\text { vanje studenata }\end{array}$ & $2 \%$ & $2 \%$ & $16 \%$ & $38 \%$ & $42 \%$ \\
\hline Studije slučajeva & $0 \%$ & $0 \%$ & $14 \%$ & $40 \%$ & $46 \%$ \\
\hline Simulacijske igre & $0 \%$ & $0 \%$ & $6 \%$ & $40 \%$ & $54 \%$ \\
\hline \multicolumn{6}{|l|}{ 2020. godina } \\
\hline Ex-chatedra & $10 \%$ & $27 \%$ & $36 \%$ & $23 \%$ & $5 \%$ \\
\hline $\begin{array}{l}\text { Aktivno sudjelo- } \\
\text { vanje studenata }\end{array}$ & $0 \%$ & $2 \%$ & $10 \%$ & $41 \%$ & $48 \%$ \\
\hline Studije slučajeva & $0 \%$ & $2 \%$ & $12 \%$ & $48 \%$ & $38 \%$ \\
\hline Simulacijske igre & $10 \%$ & $27 \%$ & $36 \%$ & $23 \%$ & $5 \%$ \\
\hline
\end{tabular}

Izvor: istraživanje autorice (2020), Zoroja (2009).

Tablica 4 prikazuje statističku značajnost razlika u postocima između 2009. i 2020. godine s obzirom na nastavne metode koje najviše pridonose zadovoljstvu studenata prema procjeni ispitanika. Statistički značajna razlika uz $10 \%$ vjerojatnosti postoji za ex-chatedra održavanje nastave $\left(\chi^{2}=8,914\right.$; - vrijednost $\left.=0,063\right)$, dok statistički značajna razlika uz $1 \%$ vjerojatnosti postoji za primjenu simulacijskih igara $\left(\chi^{2}=103,108\right.$; $p$ - vrijednost $\left.=0,000\right)$. Nakon 11 godina, značajno se smanjio udio ispitanika koji smatraju kako simulacijske igre znatno pridonose zadovoljstvu studenata. Daljnjim analizama i istraživanjem, potrebno je utvrditi moguće razloge.

Tablica 5 prikazuje rezultate provedene deskriptivne statistike vezano uz procjenu zadovoljstva studenata primjenom različitih nastavnih metoda. Najnižu prosječnu ocjenu ima kategorija Ex-chatedra za obje promatrane godine (2009.: 2,54; 2020.: 2,86). Ostale kategorije u obje promatrane godine imaju prosječnu ocjenu iznad četiri. Rezultati istraživanja iz 2009. godine pokazuju kako najveću prosječnu ocjenu ima kategorija Simulacijske igre $(4,48)$, dok u 2020. godini najveću prosječnu ocjenu ima kategorija Aktivno sudjelovanje $(4,35)$.

Promatrajući dobivene rezultate za 2009. i 2020. godinu, moguće je zaključiti kako ispitanici smatraju da primjena simulacijskih igara odnosno aktivnog sudjelovanja studenata u nastavi, pridonose njihovom zadovoljstvu. Rezultati t-testa su pokazali kako statistički značajna razlika uz $10 \%$ vjerojatnosti postoji za kategoriju Ex-chatedra (p-vrijednost 0,0669), dok za kategoriju Simulacijske igre, statistički značajna razlika postoji uz $5 \%$ 
Tablica 4. Hi-kvadrat test razlika stavova ispitanika iz uzorka s obzirom na nastavne metode koje najviše pridonose zadovoljstvu studenata (2009. i 2020. godina)

\begin{tabular}{|c|c|}
\hline $\begin{array}{c}\text { Nastavne metode koje najviše pridonose } \\
\text { zadovoljstvu studenata }\end{array}$ & Hi-kvadrat \\
\hline Ex-chatedra & $\begin{array}{c}\chi^{2}=8,914 \\
\mathrm{p} \text {-vrijednost }=0,063^{*}\end{array}$ \\
\hline Aktivno sudjelovanje studenata & $\begin{array}{c}\chi^{2}=3,894 \\
\mathrm{p} \text { - vrijednost }=0,420\end{array}$ \\
\hline Studije slučajeva & $\begin{array}{c}\chi^{2}=3,643 \\
\mathrm{p} \text { - vrijednost }=0,456\end{array}$ \\
\hline Simulacijske igre & $\begin{array}{c}\chi^{2}=103,708 \\
\mathrm{p} \text { - vrijednost }=0,000 * * *\end{array}$ \\
\hline
\end{tabular}

Izvor: istraživanje autorice (2020), Zoroja (2009).

Bilješka: *** statistički značajno uz $1 \%$ vjerojatnosti; * 10 \% vjerojatnosti

Tablica 5. Nastavne metode koje najviše pridonose zadovoljstvu studenata prema procjeni ispitanika iz uzorka - usporedba prosječnih ocjena 2009. i 2020. godine

\begin{tabular}{|l|c|c|c|c|}
\hline $\begin{array}{l}\text { Deskriptivna } \\
\text { statistika }\end{array}$ & Ex-chatedra & $\begin{array}{c}\text { Aktivno } \\
\text { sudjelovanje }\end{array}$ & $\begin{array}{c}\text { Studije } \\
\text { slučajeva }\end{array}$ & $\begin{array}{c}\text { Simulacijske } \\
\text { igre }\end{array}$ \\
\hline 2009. godina \\
\hline Broj odgovora & 50 & 50 & 50 & 50 \\
\hline Aritmetička sredina & 2,54 & 4,16 & 4,32 & 4,48 \\
\hline Standardna devijacija & 1,05 & 0,91 & 0,71 & 0,61 \\
\hline 2020. godina & 124 & 124 & 124 & 124 \\
\hline Broj odgovora & 2,86 & 4,35 & 4,21 & 4,21 \\
\hline Aritmetička sredina & 1,03 & 0,72 & 0,75 & 0,82 \\
\hline Standardna devijacija & \multicolumn{5}{|l|}{} \\
\hline t-test razlike aritmetičkih sredina 2009.i 2020. godine & \\
\hline t-test & 1.8443 & 1.4562 & 0.8887 & 2.1039 \\
\hline p-vrijednost & $0,0669^{*}$ & 0,1472 & 0,3754 & $0,0368^{* *}$ \\
\hline
\end{tabular}

Izvor: istraživanje autorice (2020), Zoroja (2009)

Bilješka: ** statistički značajno uz $5 \%$ vjerojatnosti; *10\%

vjerojatnosti (p-vrijednost 0,0368). Za preostale dvije kategorije, nema statistički značajnih razlika za rezultate iz 2009. i 2020. godine. Može se zaključiti kako se stavovi akademskih djelatnika prema zadovoljstvu studenata s obzirom na korištenje različitih oblika nastave (ex-chatedra, aktivno sudjelovanje i studije slučajeva) nisu značajnije promijenili. S druge strane, ispitanici smatraju kako simulacijske igre više doprinose zadovoljstvu studenata, što je potkrijepio i podatak kako u 2020. godini veliki udio ispitanika planira koristiti simulacijske igre u obrazovnom procesu. 


\subsection{Razlika uporabe simulacijskih igara i ex-chatedra nastave}

U nastavku rada prikazat će se razlike prilikom primjene simulacijskih igara i ex-chatedra nastave. Ispitanici su na Likertovoj ljestvici od jedan do pet procijenili razliku između korištenja simulacijskih igara i ex-chatedra predavanja kroz uspjeh studenata na ispitima, razumijevanje gradiva i aktivnog sudjelovanja u nastavi (Tablica 6). Najviše ispitanika u 2009. godini je istaknulo kako postoji velika razlika ili izrazito velika razlika prilikom primjene simulacijskih igara u odnosu na ex-chatedra predavanje za sve navedene kategorije: Uspjeh studenata na ispitima (46\%), Razumijevanje gradiva (76\%) i Aktivno sudjelovanje u nastavi (76 \%). Približno su jednaki rezultati i za ponovljeno istraživanje iz 2020. godine. Većina ispitanika se slaže kako je veći doprinos primjene simulacijskih igara u svim navedenim područjima: Uspjeh studenata na ispitima (40\%), Razumijevanje gradiva (76 \%) i Aktivno sudjelovanje u nastavi (78 \%) u odnosu na ex-chatedra predavanje.

Tablica 6. Razlika primjene simulacijskih igara i ex-chatedra nastave prema procjeni ispitanika iz uzorka

\begin{tabular}{|c|c|c|c|}
\hline \multirow[b]{2}{*}{ Aspekti nastave } & \multicolumn{3}{|c|}{ Ispitanici u postocima } \\
\hline & $\begin{array}{l}\text { Nema razlika ili mala } \\
\text { razlika u odnosu na } \\
\text { prijašnji način rada } \\
\text { (1) }\end{array}$ & $\begin{array}{l}\text { Srednja razlika u } \\
\text { odnosu na prijašnji } \\
\text { način rada }(3)\end{array}$ & $\begin{array}{c}\text { Velika razlika ili iz- } \\
\text { razito velika razlika } \\
\text { u odnosu na prijašnji } \\
\text { način rada }(5)\end{array}$ \\
\hline \multicolumn{4}{|l|}{ 2009. godina } \\
\hline $\begin{array}{l}\text { Uspjeh studenata na } \\
\text { ispitima }\end{array}$ & $16 \%$ & $38 \%$ & $46 \%$ \\
\hline $\begin{array}{l}\text { Razumijevanje } \\
\text { gradiva }\end{array}$ & $8 \%$ & $16 \%$ & $76 \%$ \\
\hline $\begin{array}{l}\text { Aktivno sudjelovanje } \\
\text { u nastavi }\end{array}$ & $6 \%$ & $18 \%$ & $76 \%$ \\
\hline \multicolumn{4}{|l|}{ 2020. godina } \\
\hline $\begin{array}{l}\text { Uspjeh studenata na } \\
\text { ispitima }\end{array}$ & $16 \%$ & $44 \%$ & $40 \%$ \\
\hline $\begin{array}{l}\text { Razumijevanje } \\
\text { gradiva }\end{array}$ & $3 \%$ & $21 \%$ & $76 \%$ \\
\hline $\begin{array}{l}\text { Aktivno sudjelovanje } \\
\text { u nastavi }\end{array}$ & $2 \%$ & $19 \%$ & $79 \%$ \\
\hline
\end{tabular}

Izvor: istraživanje autorice (2020), Zoroja (2009).

Promatrajući dobivene rezultate za 2009. i 2020. godinu, moguće je zaključiti kako se najviše ispitanika slaže kako je velika odnosno izrazito velika razlika prilikom primjene simulacijskih igara u odnosu na prijašnji način rada i to području razumijevanja gradiva i aktivnog sudjelovanja u obrazovnom procesu. Međutim, rezultati Hi-kvadrat testa nisu pokazali statistički značajnu razliku između primjene simulacijskih igara i ex-chatedra nastave s obzirom na navedene aspekte nastave. Iako ispitanici smatraju kako primjena simulacijskih igara više utječe na razumijevanje gradiva i aktivno sudjelovanje u nastavi, nisu spremni koristiti ih u većoj mjeri u odnosu na ex-chatedra predavanje (Tablica 7). 
Tablica 7. Hi-kvadrat test razlika primjene simulacijskih igara i ex-chatedra nastave prema procjeni ispitanika iz uzorka (2009. i 2020. godina)

\begin{tabular}{|c|c|}
\hline Aspekti nastave & Hi-kvadrat \\
\hline Uspjeh studenata na ispitima & $\begin{array}{c}\chi^{2}=0,858 \\
\mathrm{p}-\text { vrijednost }=0,651\end{array}$ \\
\hline Razumijevanje gradiva & $\begin{array}{c}\chi^{2}=2,948 \\
\mathrm{p}-\text { vrijednost }=0,229\end{array}$ \\
\hline Aktivno sudjelovanje u nastavi & $\begin{array}{c}\chi^{2}=2,085 \\
\text { p- vrijednost }=0,353\end{array}$ \\
\hline
\end{tabular}

Izvor: istraživanje autorice (2020), Zoroja (2009).

Tablica 8 prikazuje rezultate provedene deskriptivne statistike vezano uz razliku prilikom primjenu simulacijskih igara i ex-chatedra nastave s obzirom na uspjeh studenata, razumijevanje gradiva i aktivnog sudjelovanja u nastavi. Prosječna ocjena je za dvije kategorije za rezultate iz 2009. godine prilično visoka: Razumijevanje gradiva $(3,92)$ i Aktivno sudjelovanje u nastavi $(4,04)$. Nižu prosječnu ocjenu ima kategorija Uspjeh studenata na ispitima $(3,34)$. Rezultati provedenog istraživanja u 2020. godini su pokazali približno jednaku situaciju. Dvije kategorije imaju prosječne ocjene iznad četiri: Razumijevanje gradiva $(4,45)$ i Aktivno sudjelovanje u nastavi $(4,52)$, dok nižu prosječnu ocjenu ima kategorija Uspjeh studenata na ispitima $(3,47)$. Rezultati t-testa su pokazali kako statistički značajna razlika ne postoji za navedene kategorije.

Tablica 8. Razlika primjene simulacijskih igara i ex-chatedra nastave prema procjeni ispitanika iz uzorka usporedba prosječnih ocjena 2009. i 2020. godine

\begin{tabular}{|l|c|c|c|}
\hline $\begin{array}{c}\text { Deskriptivna } \\
\text { statistika }\end{array}$ & $\begin{array}{c}\text { Uspjeh studenata } \\
\text { na ispitima }\end{array}$ & $\begin{array}{c}\text { Razumijevanje } \\
\text { gradiva }\end{array}$ & $\begin{array}{c}\text { Aktivno sudjelo- } \\
\text { vanje u nastavi }\end{array}$ \\
\hline \multicolumn{5}{|l|}{ 2009.godina } \\
\hline Broj odgovora & 50 & 50 & 50 \\
\hline Aritmetička sredina & 3,34 & 4,60 & 4,54 \\
\hline Standardna devijacija & 1,06 & 0,99 & 1,01 \\
\hline 2020. godina & \multicolumn{5}{|l}{} \\
\hline Broj odgovora & 124 & 124 & 124 \\
\hline Aritmetička sredina & 3,47 & 4,45 & 4,52 \\
\hline Standardna devijacija & 1,42 & 1,03 & 0,97 \\
\hline t-test razlike aritmetičkih sredina 2009. i 2020. godine & 0.1216 \\
\hline t-test & 0.5846 & 0.8789 & 0,9033 \\
\hline p-vrijednost & 0,5596 & 0,3807 & \\
\hline
\end{tabular}

Izvor: istraživanje autorice (2020), Zoroja (2009). 


\subsection{Korisnost uporabe simulacijskih igara za studente}

U Tablici 9 navedene su koristi primjene simulacijskih igara za studente. Ispitanici su trebali na Likertovoj ljestvici od jedan do pet ocijeniti je li primjena simulacijskih igara doprinosi studentima u radu obzirom na pripremu za stvarnu situaciju, donošenje odluka,

Tablica 9. Korisnost uporabe simulacijskih igara za studente prema procjeni ispitanika iz uzorka

\begin{tabular}{|c|c|c|c|c|c|}
\hline \multirow[b]{2}{*}{ Aspekti korisnosti } & \multicolumn{5}{|c|}{ Ispitanici u postocima } \\
\hline & $\begin{array}{l}\text { Ne dopri- } \\
\text { nose stu- } \\
\text { dentima u } \\
\text { radu }\end{array}$ & $\begin{array}{c}\text { Malo } \\
\text { doprinose } \\
\text { studentima } \\
\text { u radu }\end{array}$ & $\begin{array}{c}\text { Srednje } \\
\text { doprinose } \\
\text { studentima } \\
\text { u radu }\end{array}$ & $\begin{array}{c}\text { Dosta } \\
\text { doprinose } \\
\text { studentima } \\
\text { u radu }\end{array}$ & $\begin{array}{c}\text { Znatno } \\
\text { doprinose } \\
\text { studentima } \\
\text { u radu }\end{array}$ \\
\hline \multicolumn{6}{|l|}{ 2009. godina } \\
\hline $\begin{array}{l}\text { Priprema za stvarnu } \\
\text { situaciju }\end{array}$ & $4 \%$ & $0 \%$ & $14 \%$ & $24 \%$ & $58 \%$ \\
\hline Donošenje odluka & $2 \%$ & $0 \%$ & $12 \%$ & $34 \%$ & $52 \%$ \\
\hline $\begin{array}{l}\text { Razvijanje analitičkih } \\
\text { sposobnosti }\end{array}$ & $0 \%$ & $0 \%$ & $16 \%$ & $44 \%$ & $40 \%$ \\
\hline Aktivno učenje & $0 \%$ & $0 \%$ & $18 \%$ & $26 \%$ & $56 \%$ \\
\hline $\begin{array}{l}\text { Učenje na pogreška- } \\
\text { ma }\end{array}$ & $0 \%$ & $2 \%$ & $26 \%$ & $34 \%$ & $38 \%$ \\
\hline $\begin{array}{l}\text { Interdisciplinaran } \\
\text { pristup problemu }\end{array}$ & $0 \%$ & $12 \%$ & $32 \%$ & $28 \%$ & $28 \%$ \\
\hline Rad u skupini & $0 \%$ & $4 \%$ & $16 \%$ & $36 \%$ & $44 \%$ \\
\hline $\begin{array}{l}\text { Komunikacijske } \\
\text { vještine }\end{array}$ & $2 \%$ & $10 \%$ & $32 \%$ & $38 \%$ & $18 \%$ \\
\hline \multicolumn{6}{|l|}{ 2020. godina } \\
\hline $\begin{array}{l}\text { Priprema za stvarnu } \\
\text { situaciju }\end{array}$ & $0 \%$ & $6 \%$ & $15 \%$ & $65 \%$ & $14 \%$ \\
\hline Donošenje odluka & $0 \%$ & $2 \%$ & $13 \%$ & $65 \%$ & $20 \%$ \\
\hline $\begin{array}{l}\text { Razvijanje analitičkih } \\
\text { sposobnosti }\end{array}$ & $0 \%$ & $2 \%$ & $6 \%$ & $57 \%$ & $35 \%$ \\
\hline Aktivno učenje & $0 \%$ & $2 \%$ & $5 \%$ & $53 \%$ & $40 \%$ \\
\hline $\begin{array}{l}\text { Učenje na } \\
\text { pogreškama }\end{array}$ & $0 \%$ & $2 \%$ & $9 \%$ & $50 \%$ & $39 \%$ \\
\hline $\begin{array}{l}\text { Interdisciplinaran } \\
\text { pristup problemu }\end{array}$ & $0 \%$ & $3 \%$ & $17 \%$ & $52 \%$ & $28 \%$ \\
\hline Rad u skupini & $0 \%$ & $2 \%$ & $17 \%$ & $49 \%$ & $32 \%$ \\
\hline $\begin{array}{l}\text { Komunikacijske } \\
\text { vještine }\end{array}$ & $0 \%$ & $3 \%$ & $23 \%$ & $46 \%$ & $27 \%$ \\
\hline
\end{tabular}

Izvor: istraživanje autorice (2020), Zoroja (2009) 
Tablica 10. Korisnost uporabe simulacijskih igara za studente prema procjeni ispitanika iz uzorka - usporedba prosječnih ocjena 2009. i 2020. godine

\begin{tabular}{|c|c|c|c|c|c|c|c|c|}
\hline $\begin{array}{c}\text { Deskriptivna } \\
\text { statistika }\end{array}$ & $\begin{array}{c}\text { Priprema } \\
\text { za stvarnu } \\
\text { situaciju }\end{array}$ & $\begin{array}{c}\text { Donošenje } \\
\text { odluka }\end{array}$ & $\begin{array}{c}\text { Razvijanje } \\
\text { analitičkih } \\
\text { sposobno- } \\
\text { sti }\end{array}$ & $\begin{array}{l}\text { Aktivno } \\
\text { učenje }\end{array}$ & $\begin{array}{c}\text { Uče na } \\
\text { pogreška- } \\
\text { ma }\end{array}$ & $\begin{array}{l}\text { Interdis- } \\
\text { ciplinaran } \\
\text { pristup } \\
\text { problemu }\end{array}$ & $\begin{array}{l}\text { Rad u } \\
\text { skupini }\end{array}$ & $\begin{array}{c}\text { Komu- } \\
\text { nikacijske } \\
\text { vještine }\end{array}$ \\
\hline \multicolumn{9}{|l|}{ 2009. godina } \\
\hline Broj odgovora & 50 & 50 & 50 & 50 & 50 & 50 & 50 & 50 \\
\hline Aritmetička sredina & 4,32 & 4,34 & 4,24 & 4,38 & 4,08 & 3,72 & 4,20 & 3,60 \\
\hline $\begin{array}{l}\text { Standardna } \\
\text { devijacija }\end{array}$ & 1,00 & 0,85 & 0,72 & 0,78 & 0,85 & 1,01 & 0,86 & 0,97 \\
\hline \multicolumn{9}{|l|}{ 2020. godina } \\
\hline Broj odgovora & 124 & 124 & 124 & 124 & 124 & 124 & 124 & 124 \\
\hline Aritmetička sredina & 3,90 & 4,02 & 4,24 & 4,32 & 4,27 & 4,04 & 4,10 & 3,98 \\
\hline $\begin{array}{l}\text { Standardna } \\
\text { devijacija }\end{array}$ & 0,72 & 0,65 & 0,67 & 0,64 & 0,69 & 0,76 & 0,76 & 0,80 \\
\hline \multicolumn{9}{|c|}{ t-test razlike aritmetičkih sredina 2009. i 2020. godine } \\
\hline t-test & 3,0964 & 2,6801 & 0,0000 & 0,5245 & 1,5345 & 2,2771 & 0,7558 & 2,7644 \\
\hline p-vrijednost & $0,0023 * * *$ & $0,0008 * * *$ & 1,0000 & 0,6006 & 0,1265 & $0,0240 * *$ & 0,4508 & $0,0063 * * *$ \\
\hline
\end{tabular}

Izvor: istraživanje autorice (2020), Zoroja (2009).

Bilješka: *** statistički značajno uz $1 \%$ vjerojatnosti; ** $5 \%$ vjerojatnosti 
razvijanje analitičkih sposobnosti, aktivno učenje, učenje na pogreškama, interdisciplinaran pristup problemu, rad u skupini i komunikacijske vještine.

Više od polovine ispitanika u 2009. godini je za sljedeće kategorije navelo kako simulacijske igre znatno doprinose studentima u radu: Priprema za stvarnu situaciju (58 \%), Donošenje odluka (52 \%), Aktivno učenje (56\%). Poprilično veliki udio ispitanika je i ostale kategorije ocijenio ocjenom pet odnosno kako simulacijske igre znatno doprinose studentima u radu: Razvijanje analitičkih sposobnosti (40 \%), Učenje na pogreškama (38 \%), Rad u skupini (44\%), kao i ocjenom četiri, kako simulacijske igre dosta doprinose studentima u radu: Razvijanje analitičkih sposobnosti (44\%), Rad u skupini (36\%), Komunikacijske vještine (38\%). U 2020. godini, više od polovine ispitanika su gotovo sve navedene kategorije ocijenili ocjenom vrlo dobar: Priprema za stvarnu situaciju (65\%), Donošenje odluka (65\%), Razvijanje analitičkih sposobnosti (57 \%), Aktivno učenje (53\%), Učenje na pogreškama (50\%), Interdisciplinaran pristup problemu (52\%). Ocjenom pet najviše ispitanika je ocijenilo sljedeće kategorije: Razvijanje analitičkih sposobnosti (35\%), Aktivno učenje (40 \%), Učenje na pogreškama (40 \%) i Rad u skupini(32 \%). Iznimno mali udio ispitanika smatra kako simulacijske igre ne pridonose odnosno malo doprinose studentima u nastavi u navedenim kategorijama za obje promatrane godine.

Tablica 10 prikazuje rezultate provedene deskriptivne statistike vezano uz korisnost primjene simulacijskih igara za studente. Prosječna ocjena za većinu kategorija za rezultate iz 2009. godine je prilično visoka, iznad četiri. Rezultati provedenog istraživanja u 2020. godini su pokazali približno jednake prosječne ocjene kao i u 2009. godini koje su također za većinu kategorija iznad četiri. Najveću prosječnu ocjenu ima kategorija Aktivno učenje u obje promatrane godine (2009.: 4,38, 2020.: 4,32).

Promatrajući dobivene rezultate za 2009. i 2020. godinu, moguće je zaključiti kako ispitanici smatraju da uporaba simulacijskih igara u navedenim kategorijama uvelike doprinosi studentima. Rezultati t-testa su pokazali kako statistički značajna razlika uz $1 \%$ vjerojatnosti postoji za sljedeće kategorije Priprema za stvarnu situaciju (p-vrijednost 0,0023), Donošenje odluka (p-vrijednost 0,0008), Komunikacijske vještine (p-vrijednost 0,0063). Za kategoriju Interdisciplinaran pristup rješavanju problema postoji statistički značajna razlika uz $5 \%$ vjerojatnosti (p-vrijednost 0,0240 ). Za preostale četiri kategorije, nema statistički značajnih razlika za rezultate iz 2009. i 2020. godine. Rezultati istraživanja iz 2020. godine pokazuju kako ispitanici u većoj mjeri smatraju kako simulacijske igre pridonose razvoju različitih sposobnosti i vještina studenata potrebnih u poslovanju, pri čemu se ističe praktičan rad, donošenje odluka, interdisciplinarnost i komunikativnost.

\subsection{Utjecaj simulacijskih igara na poboljšanje izvođenja nastave predavača}

U ovom dijelu rada predstavit će se utjecaj primjene simulacijskih igara na izvođenje nastave. Ispitanici su trebali na Likertovoj ljestvici od jedan do pet ocijeniti jesu li uporabom simulacijskih igara poboljšali kvalitetu vlastitoga rada, efikasnije prenošenje znanja i daljnje uvođenje inovacija u rad sa studentima (Tablica 11).

Najviše ispitanika je 2009. godine navelo kako simulacijske igre imaju vrlo dobar učinak na radnu sposobnost nastavnika i to u području Efikasnije prenošenje znanja (46 \%) 
i Uvođenje inovacija u rad (50 \%). U 2020. godini, također je polovina ispitanika sve tri kategorije ocijenila ocjenom vrlo dobar: Poboljšala se kvaliteta mojega rada (50\%), Efikasnije prenošenje znanja (51 \%) i Uvođenje inovacija u rad (49 \%). Promatrajući dobivene rezultate za 2009. i 2020. godinu, moguće je zaključiti kako je gotovo duplo više ispitanika u 2009. godini za dvije kategorije procijenilo kako primjena simulacijskih igara ima izvrstan učinak na njihovu radnu sposobnost u odnosu na rezultate iz 2020. godine: Poboljšala se kvaliteta mojega rada (2009.: 42 \%; 2020.: 23 \%) i Efikasnije prenošenje znanja (2009.: 42 \%; 2020.: $26 \%)$.

Tablica 11. Poboljšanje radne sposobnosti predavača primjenom simulacijskih igara prema procjeni ispitanika iz uzorka

\begin{tabular}{|c|c|c|c|c|c|}
\hline \multirow[b]{2}{*}{ Aspekti poboljšanja } & \multicolumn{5}{|c|}{ Ispitanici u postocima } \\
\hline & $\begin{array}{c}\text { Ne- } \\
\text { dovoljan } \\
\text { učinak } \\
\text { na radnu } \\
\text { sposobnost }\end{array}$ & $\begin{array}{c}\text { Dovoljan } \\
\text { učinak } \\
\text { na radnu } \\
\text { sposobnost }\end{array}$ & $\begin{array}{l}\text { Dobar } \\
\text { učinak } \\
\text { na radnu } \\
\text { sposobnost }\end{array}$ & $\begin{array}{l}\text { Vrlo dobar } \\
\text { učinak } \\
\text { na radnu } \\
\text { sposobnost }\end{array}$ & $\begin{array}{c}\text { Izvrstan } \\
\text { učinak } \\
\text { na radnu } \\
\text { sposobnost }\end{array}$ \\
\hline \multicolumn{6}{|l|}{ 2009. godina } \\
\hline $\begin{array}{l}\text { Uporabom simulacijski } \\
\text { igara poboljšala se kvalite- } \\
\text { ta mojega rada }\end{array}$ & $0 \%$ & $0 \%$ & $26 \%$ & $32 \%$ & $42 \%$ \\
\hline $\begin{array}{l}\text { Uporabom simulacijskih ig- } \\
\text { ara efikasnije i lakše preno- } \\
\text { sim znanje studentima }\end{array}$ & $0 \%$ & $0 \%$ & $12 \%$ & $46 \%$ & $42 \%$ \\
\hline $\begin{array}{l}\text { Simulacijske igre me potiču } \\
\text { na uvođenje daljnjih ino- } \\
\text { vacija u radu sa studentima }\end{array}$ & $0 \%$ & $2 \%$ & $10 \%$ & $50 \%$ & $38 \%$ \\
\hline \multicolumn{6}{|l|}{ 2020. godina } \\
\hline $\begin{array}{l}\text { Uporabom simulacijskih } \\
\text { igara poboljšala se kvalite- } \\
\text { ta mojega rada }\end{array}$ & $1 \%$ & $2 \%$ & $24 \%$ & $50 \%$ & $23 \%$ \\
\hline $\begin{array}{l}\text { Uporabom simulacijskih } \\
\text { igara efikasnije i lakše } \\
\text { prenosim znanje studen- } \\
\text { tima }\end{array}$ & $1 \%$ & $1 \%$ & $21 \%$ & $51 \%$ & $26 \%$ \\
\hline $\begin{array}{l}\text { Simulacijske igre me potiču } \\
\text { na uvođenje daljnjih ino- } \\
\text { vacija u radu sa studentima }\end{array}$ & $1 \%$ & $1 \%$ & $24 \%$ & $50 \%$ & $24 \%$ \\
\hline
\end{tabular}

Izvor: istraživanje autorice (2020), Zoroja (2009).

Tablica 12 prikazuje rezultate provedene deskriptivne statistike vezano uz poboljšanje izvođenja nastave primjenom simulacijskih igara. Prosječna ocjena za sve tri kategorije za rezultate iz 2009. godine je prilično visoka, iznad četiri: Poboljšala se kvaliteta mojega rada $(4,13)$, Efikasnije prenošenje znanja $(4,20)$ i Uvođenje inovacija u rad $(4,13)$. Rezultati 
provedenog istraživanja u 2020. godini su pokazali približno jednake prosječne ocjene za tri navedene kategorije: Poboljšala se kvaliteta mojega rada (3,91), Efikasnije prenošenje znanja $(3,99)$ i Uvođenje inovacija u rad $(3,95)$. Promatrajući dobivene rezultate za 2009. i 2020. godinu, moguće je zaključiti kako nastavnici smatraju kako bi primjenom simulacijskih igara poboljšali izvođenje nastave.

Rezultati t-testa su pokazali kako statistički značajna razlika uz $10 \%$ vjerojatnosti postoji za kategoriju Efikasnije prenošenje znanja studentima primjenom simulacijskih igara (p-vrijednost 0.0988). Za preostale dvije kategorije, nema statistički značajnih razlika za rezultate iz 2009. i 2020. godine. Prema dobivenim rezultatima, moguće je zaključiti kako ispitanici smatraju da simulacijske igre imaju pozitivan učinak na njihov rad, ali zbog postojanja ograničavajućih faktora, koje je potrebno daljnje istražiti, još uvijek ih ne koriste u velikoj mjeri u nastavi.

Tablica 12. Poboljšanje radne sposobnosti predavača primjenom simulacijskih igara prema procjeni ispitanika iz uzorka - usporedba prosječnih ocjena 2009. i 2020. godine

\begin{tabular}{|l|c|c|c|}
\hline \multicolumn{1}{|c|}{$\begin{array}{c}\text { Deskriptivna } \\
\text { statistika }\end{array}$} & $\begin{array}{c}\text { Uporabom simu- } \\
\text { lacijskih igara se } \\
\text { poboljšala kvaliteta } \\
\text { mojega rada }\end{array}$ & $\begin{array}{c}\text { Uporabom simulacij- } \\
\text { skih igara učinkovi- } \\
\text { tije i lakše prenosim } \\
\text { znanje studentima }\end{array}$ & $\begin{array}{c}\text { Simulacijske igre me } \\
\text { potiču na uvođenje } \\
\text { daljnjih inovacija u } \\
\text { radu sa studentima }\end{array}$ \\
\hline 2009. godina & 50 & 50 & 50 \\
\hline Broj odgovora & 4,13 & 4,20 & 4,13 \\
\hline Aritmetička sredina & 0,82 & 0,61 & 0,73 \\
\hline Standardna devijacija & 98 & 98 & 98 \\
\hline 2020. godina & 3,91 & 3,99 & 3,95 \\
\hline Broj odgovora** & 0,80 & 0,78 & 0,79 \\
\hline Aritmetička sredina & \multicolumn{5}{|c|}{} \\
\hline Standardna devijacija & 1.5691 & 1.6612 & 1.3444 \\
\hline t-test razlike aritmetičkih sredina 2009. i 2020. godine & $0,0988^{*}$ & 0,1809 \\
\hline t-test & 0,1188 & & \\
\hline p-vrijednost & \multicolumn{5}{|c|}{} \\
\hline
\end{tabular}

Izvor: istraživanje autorice (2020), Zoroja (2009).

Bilješka: * statistički značajno uz $10 \%$ vjerojatnosti; ** na navedeno pitanje je odgovorilo 98 ispitanika

\section{ZAKLJUČAK}

Digitalne tehnologije imaju veliku ulogu u privatnom i poslovnom segmentu života, jer kreiraju okruženje koje potiče inovativnost i stvara nove mogućnosti. Upravo stoga, fakulteti kroz proces visokog obrazovanja trebaju poticati na primjenu inovativnog pristupa učenju kroz kombinaciju različitih nastavnih metoda kako bi se prilagodili digitalnom okruženju i visokim zahtjevima studenata. Potrebno je promijeniti dosadašnji način rada koji je bio orijentiran na nastavni proces i fokusirati se na studente i kreiranje okruženja koje će ih potaknuti na sudjelovanje. Upravo primjena simulacijskih igara ima značajnu 
ulogu u obrazovnom procesu, jer motivira studente i potiče ih na aktivno sudjelovanje. Od sudionika simulacijske igre očekuje se da aktivno prate dinamiku okruženja i izazova koji se pred njih stavljaju kako bi pravodobno donijeli kvalitetne odluke i bili bolji od konkurencije. Kroz sudjelovanje u virtualnom okruženju, sudionici imaju mogućnost donositi odluke i analizirati ih te u vrlo kratkom periodu vidjeti posljedice svojih odluka na poslovanje, čime se osigurava učenje kroz iskustvo.

Namjera rada je istražiti primjenu simulacijskih igara u nastavnom procesu kao i zadovoljstvo studenata prilikom korištenja simulacijskih igara te utvrditi razliku prilikom primjene različitih nastavnih metoda u obrazovnom procesu. Cilj rada je predstaviti rezultate o primjeni simulacijskih igara u nastavi u 2020. godini te usporediti dobivene rezultate empirijskog istraživanja iz 2020. godine s rezultatima istraživanja provedenog 2009. godine među nastavnicima koji su zaposleni na ekonomskim fakultetima u Republici Hrvatskoj. Kroz postavljena pitanja iz anketnog upitnika, ispitanici su naveli vlastite stavove i promišljanja o primjeni simulacijskih igara, a procijenili su i značaj primjene simulacijskih igara na kvalitetu izvođenja nastave, ali i na rad studenata. Kako bi se ostvarili ciljevi, provedena je deskriptivna analiza kao i Hi-kvadrat test kako bi se istražilo postojanje statističke značajnosti među varijablama.

Doprinos rada postojećoj znanstvenoj literaturi iz područja simulacijskih igara proizlazi iz primarnog empirijskog istraživanja provedenog 2020. i 2009. godine o primjeni simulacijskih igara u nastavi i njihovom utjecaju na kvalitetu nastave i doprinosu zadovoljstva studenata. Rezultati provedenog istraživanja u 2020. godini pokazali su kako se stavovi ispitanika o primjeni simulacijskih igara u obrazovnom procesu nisu značajno promijenili unatoč proteku od 11 godina. Ispitanici smatraju kako simulacijske igre pridonose razvoju različitih znanja i vještina studenata te kako povećavaju kvalitetu izvedbe nastavnog procesa. Unatoč opisanim prednostima primjene poslovnih simulacijskih igara u nastavi, i za studente i za nastavnike, koje su potvrdili i rezultati primarnog empirijskog istraživanja iz 2009. i 2020. godine, iste nisu zastupljene u obrazovnom procesu u velikoj mjeri i veći dio nastave se odvija bez velikog udjela aktivnog sudjelovanja studenata primjenom različitih digitalnih tehnologija. Nažalost, udio ispitanika koji koriste simulacijske igre smanjio se nakon 11 godina. O potencijalnim razlozima moguce je samo raspravljati te istražiti ih u sljedećim istraživanjima. Mogući razlozi nekorištenja simulacijskih igara u nastavi mogu biti nespremnost nastavnika na primjenu simulacijskih igara i promjenu dosadašnjeg načina rada, nespremnost studenata na aktivno sudjelovanje u obrazovnom procesu, financijska sredstava, loša informacijsko-komunikacijska infrastruktura. Rezultati provedenog istraživanja korisni su kako za istraživače odnosno znanstvenike, tako i za menadžere u poslovnom sektoru. $\mathrm{Na}$ osnovu predstavljenih rezultata, istraživači mogu provesti buduća istraživanja te primijeniti dublje i detaljnije statističke analize kako bi utvrdili razloge koji sprječavaju širu primjenu simulacijskih igara. Osim toga, menadžerima u poslovnom sektoru predstavljeni rezultati mogu koristiti prilikom edukacije zaposlenika kako bi kroz sudjelovanje u simulacijskim igrama stekli neophodna poslovna znanja i vještine. Upravo stoga, ovaj rad može ukazati i potaknuti na veću primjenu simulacijskih igara u obrazovnom procesu čime bi se studenti više motivirali i potaknuli na kritičko razmišljanje i razvoj kognitivnih sposobnosti.

Iako rad omogućava uvid u trenutno stanje primjene simulacijskih igara na ekonomskim fakultetima u Hrvatskoj, provedeno istraživanje i predstavljeni rezultati imaju ograni- 
čenja koja osiguravaju buduće smjernice istraživanja. Najveći nedostatak rada predstavlja uzorak koji nije u potpunosti usporediv za obje godine za koje se provodi istraživanje. Također, potrebno je istražiti više informacija vezano uz ispitanike, kao što su: katedra na kojoj su zaposleni, područje istraživanja, vrsta nastave koju izvode, iskustva s primjenom simulacijskih igara, razlozi korištenja simulacijskih igara. Osim toga, istraživanje je fokusirano na četiri područja primjene i utjecaja simulacijskih igara na obrazovni proces i zadovoljstvo studenata, dok je u budućim istraživanjima potrebno istražiti i dodatna područja. Potrebno je i proširiti istraživanje na zemlje u regiji te ostale ekonomske fakultete, što bi dodatno pridonijelo relevantnosti i reprezentativnosti empirijskih rezultata te bi omogućilo usporedbu između pojedinih zemalja. Buduće analize iz navedenog područja trebalo bi usmjeriti i na istraživanja koja bi se provela među studentima kako bi otkrili kakva su njihova promišljanja o obrazovnom procesu i o načinu njegova provođenja te o primjeni simulacijskih igara u nastavi. Također, potrebno je kroz dubinske intervjue dodatno istražiti stavove i iskustva nastavnika o primjeni simulacijskih igara u obrazovnom procesu, kao i o razlozima njihove nedovoljne primjene u obrazovanju.

\section{LITERATURA}

1. Bell, B. S., Kanar, A. M., Kozlowski, S. W. (2008). Current issues and future directions in simulation-based training in North America. The International Journal of Human Resource Management, Vol. 19, No. 8, str. 1416-1434.

2. Bell, R., Loon, M. (2015). Reprint: The impact of critical thinking disposition on learning using business simulations. The International Journal of Management Education, Vol. 13, No. 2, str. 1-9.

3. Clark, D. B., Tanner-Smith, E. E., Killingsworth, S. S. (2016). Digital games, design, and learning: A systematic review and meta-analysis. Review of Educational Research, Vol. 86, No. 1, str.79-122.

4. Dankbaar, M. E. W., Alsma, J., Jansen, E. E. H., van Merrienboer, J. J. G., van Saase, J. L. C. M., Schuit, S. C. E. (2016). An experimental study on the effects of a simulation game on students' clinical cognitive skills and motivation. Advances in Health Sciences Education, Vol. 21, str. 505-521.

5. De Smale, S., Overmans, T., Jeuring, J., van de Grint, L. (2015). The effect of simulations and games on learning objectives in tertiary education: A systematic review. In International Conference on Games and Learning Alliance, str. 506-516, Cham: Springer.

6. Fasli, M., Michalakopoulos, M. (2006). Learning Through Game-like Simulations. Innovation in Teaching and Learning in Information and Computer Sciences, Vol. 5, No. 2, str. 1-11.

7. Goi, C.L. (2019). The use of business simulation games in teaching and learning. Journal of Education for Business, Vol. 94, No. 5, str. 342-349.

8. Gredler, M. (2004). Games and simulations and their relationships to learning. In D. H. Jonassen (ed.), Handbook of research for educational communications and 
technology - A project of the association for educational communications and technology, str. 571-581, Mahwah, NJ: Lawrence Erlbaum.

9. Hu, Y., Min Wong, R., Adesope, O., Taylor, M. E. (2020). Effects of a computer-based learning environment that teaches older adults how to install a smart home system. Computers \& Education, Vol. 149, 103816.

10. Lainemaa, T., Nurmib, S. (2006). Applying an authentic, dynamic learning environment in real world business. Computers \& Education, Vol. 47, No. 1, str. 95-115.

11. Mawhirter, D. A., Garofalo, P. F. (2016). Expect the Unexpected: Simulation Games as a Teaching Strategy. Clinical Simulation in Nursing, Vol. 12, No. 4, str. 132-136.

12. Mohsen, K., Abdollahi, S., Omar, S. (2019) Evaluating the educational value of simulation games: Learners' perspective. Innovations in Education and Teaching International, Vol. 56, No. 4, str. 517-528.

13. Nkhoma, M., Calbeto, J., Sriratanaviriyakul, N., Muang, T., Ha Tran, Q., Kim Cao, T. (2014). Towards an understanding of real-time continuous feedback from simulation games. Interactive Technology and Smart Education, Vol. 11, No. 1, str. 45-62.

14. Ranchhod, A., Gurău, C., Loukis, E., Trivedi, R. (2014). Evaluating the educational effectiveness of simulation games: A value generation model. Information Sciences, Vol. 264, str. 75-90.

15. Rutten, N., Van Joolingen, W. R., Van Der Veen, J. T. (2012). The learning effects of computer simulations in science education. Computers \& Education, Vol. 58, No. 1, str. 136-153.

16. Sanina, A., Kutergina, E., Balashov, A. (2020). The Co-Creative approach to digital simulation games in social science education. Computers \& Education, Vol. 149, 103-813.

17. Siewiorek, A., Gegenfurtner, A., Lainema, T., Saarinen, E., Lehtinen, E. (2013). The effects of computer-simulation game training on participants' opinions on leadership styles. British Journal of Educational Technology, Vol. 44, No. 6, str. 1012-1035.

18. Strahilov, A., Damrath, F. (2015). Simulation of the behavior of pneumatic drives for virtual commissioning of automated assembly systems. Robotics and Computer-Integrated Manufacturing, Vol. 36, str. 101-108.

19. Vlachopoulos, D., Makri, A. (2017). The Effect of Games and Simulations on Higher Education: A Systematic Literature Review. International Journal of Educational Technology in Higher Education, Vol. 14, No. 22, str. 1-33.

20. Zoroja, J. (2009). Korištenje simulacijskih igara u hrvatskim obrazovnim institucijama ekonomskih znanosti u Republici Hrvatskoj. Zbornik Ekonomskog fakulteta u Zagrebu, Vol. 7, No. 2, str. 101-113.

21. Zulfiqar, S., Zhou, R., Asmi, F., Yasin, A. (2018). Using simulation system for collaborative learning to enhance learner's performance. Cogent Education, Vol. 5, str. 1-13. 